\title{
Compensation Practices on Job Satisfaction of Faculty Members in Private HEI in Saudi Arabia: Mediating Role of Talent Management
}

\author{
Zainab Bello (Corresponding author) \\ Dept. of Human Resource Management, ALASALA University \\ PO Box 12666, Dammam, 31483, Saudi Arabia \\ E-mail: zbello03@yahoo.com \\ Waleed Alhyasat \\ College of Business and Management, Fahad Bin Sultan University \\ P.O Box 15700, Tabuk, 71454, Saudi Arabia \\ E-mail: walhyasat@fbsu.edu.sa
}

Received: Aug. 24, $2020 \quad$ Accepted: Sep. 21, 2020 Online published: Oct. 15, 2020

doi:10.5296/ijhrs.v10i4.17838ＵRL: https://doi.org/10.5296/ijhrs.v10i4.17838

\begin{abstract}
Purpose- The paper examined the role of compensation practices on job satisfaction of faculty members in private institutions of higher learning in Saudi Arabia. The paper also examined the mediating role of talent management in the relationship between compensation practices and job performance.
\end{abstract}

Methodology/Approach- A descriptive research design method was applied in the study. The paper is focused on review of previous studies from online data bases and periodicals on the paper variables and resultant relationships. Literature acknowledged the effect of compensation practices on job satisfaction. The paper explained the importance of compensation practices on job satisfaction and the mediating role of talent management. Equity theory was used as the underpinning theory of this paper.

Findings- The paper found that compensation practice mediated by talent management is important to increase job satisfaction of faculty members of newly established private institutions of higher learning particularly in Saudi Arabia. 
Implication/Contribution- The paper provides opportunity for scholars to test the proposed framework empirically. The paper can serve as guide for human resource personnel in newly established private institutions of learning in increasing faculty member's job satisfactions. The paper adds to body of existing literature on compensation practices, job satisfaction and talent management with focus on newly established private institution of learning in Saudi Arabia.

Keywords: job satisfaction, compensation practices, talent management, faculty members, Saudi Arabia

\section{Conceptual Paper}

\section{Introduction}

Educational institutions play an important role in the growth of a country as it is the sector that is essential for the development of a nation as well as providing knowledge. It is therefore necessary to have highly talented faculty members as these institutions of higher learning contributes immensely in skills development hence improves economy of a country (Mabaso and Dlamini, 2017).

The key element in the success of organizations is their employees (Ismail and Abd-Razak, 2016; Gupta, 2014). Faculty members are employees in institution of higher learning and the success of these institutions is highly dependent on the commitment level of these faculty members (Mabaso and Dlamini, 2017). A satisfied employee usually exhibits positive work attitudes (Ismail and Abd-Razak, 2016). This is why higher institutions do all they can to ensure their employees are satisfied, dedicated and loyal with adequate compensation practices.

Institutions of higher learning can achieve certain levels of employee's job satisfaction through their compensation practices (Mabaso and Dlamini, 2017). It has been stated that faculty members that are compensated adequately are motivated to put more effort in their jobs (Ismail and Abd-Razak, 2016).

Organizations have applied compensation practices that have effects on job satisfaction differently be it private or public (Gupta, 2014). This is usually in accordance with the standards in each of the industries (Gupta, 2014). The type of compensation practices used is essential to motivate increased productivity from employees. Therefore, compensation practices assists in effectively managing organization human resources in achieving set objectives (Absar et al., 2010).

The public institutions of higher learning in the gulf region have gradually over the years mastered the act of compensating their employees (Mabaso and Dlamini, 2017). This has made compensation a competitive practice in the gulf region (Mustafa, 2013).

Furthermore, this has been attributed to the fact that the competitive the compensation practiced, the more the institution of higher learning can attract and retain top faculty talents (Absar et al., 2010). This is because compensation practices are incentives institution and corporation put in place to ensure job satisfaction through talent management (Hamidi, Saberi, 
and Safari, 2014).

Talent management of human capital is essential in the achievement of organizational goals. According to Hamidi et al. (2014) this is achievable through job satisfaction and compensation practice is one of the ways to ensure job satisfaction. Since employees are the most valuable asset of any organization, talent management is an important variable in ensuring that there is equity in compensation practices to improve job satisfaction (Kamal and Lukman, 2017).

It has been stated that institutions of higher learning have come to recognize the impact adequate talent management and compensation practices have on job satisfaction (Kamal and Lukman, 2017). However, there are issues in its practice and implementations particularly in private institutions of learning in Saudi Arabia (Albaqami, 2016), hence the need for further investigation of the variables.

Previous research has been conducted on the effect of compensation practices on job satisfaction; compensation practice and talent management and on talent management and job satisfaction in different research settings (Hafez, AbouelNeel and Elsaid, 2017; Hamidi et al., 2014; Kamal and Lukman, 2017; Mabaso and Dlamini, 2017). However, this paper authors have no knowledge of research in which talent management mediates the relationship between compensation practices and job satisfaction with focus on private institution of higher learning in Saudi Arabia. This leaves a gap for investigation (Hafez et al., 2017). Therefore, the objective of this paper is to examine the mediating role of talent management in the relationship between compensation practices and job satisfaction of faculty members in newly established private institutions of higher learning in Saudi Arabia. Thus the research questions for this paper are as follows:

1. Does Compensation Practices have significant relationship with Job Satisfaction?

2. What is the relationship between Compensation Practices and Talent Management?

3. What is the relationship between Talent Management and Job Satisfaction?

4. Does Talent Management mediate the relationship between Compensation Practices and Job Satisfaction?

\section{Literature Review and Hypotheses}

\subsection{Job Satisfaction}

Job satisfaction has been defined as emotional achievement of employees with regards to assigned tasked within an educational setting (Moloantoa, 2015). It is those short-lived events that may make employees to re-assess their attachment to the job and hence the organization (Karim and Rehman, 2012). Furthermore, job satisfaction is the individual assessment of their work roles and experiences.

One remarkable area in the management of human resource in an organization is the issue of job satisfaction. This is because employee's well-being and welfare are essential to determination of job satisfaction (Bustamam, Teng and Abdullah, 2014). It has been stated 
that employee's continued loyalty to their organization is due to the feeling of being satisfied with the job, which is evident in their productivity (Moloantoa, 2015).

Most employees accept to work for organizations for the social as well as the psychological security that having a job comes with. As such it is opined that for improved productivity, job satisfaction of faculty members in institutions of higher learning need to be considered (Mustafa, 2013).

According to Mabaso, and Dlamini (2017) elements like effort recognition, conditions of work, good salary structure and opportunities for promotion should be considered for faculty members to have job satisfaction (Mustafa, 2013). Faculty member's job satisfaction in institutions of higher learning is essential due to its effect in motivating the delivery of quality performance.

In addition, positive job attitude of faculty members in institutions of higher learning is essential. This is because this attitude can assist in the achievement of the set objectives as well as sustenance of the institutions (Noor, 2013). Job satisfaction has been stated to have positive effects on turnover (Noor, 2013). Therefore, the zeal of employees to work is affected by the relationship that is between employees and the organization. These relationships can be assessed through work itself and the compensation practices to reward work (Ombima, 2014).

This is because job satisfaction is among the expectations and needs employees come into organizations with (Mabaso and Dlamini, 2017). Therefore, it is important that organizations are able to satisfy these needs to avoid massive turnover or low productivity. One of the ways to satisfying these employees expected needs is through compensation practices (Absar and Azim, 2010; Gupta, 2014; Mabaso and Dlamini. 2017).This indicates that faulty members' job satisfaction is essential in institutions of higher learning (Mabaso and Dlamini, 2017; Noor, 2013; Ombima, 2014).

Research on job satisfaction of faculty members in private institutions of higher learning particularly in eastern province of Saudi Arabia is limited. Studies on job satisfaction have been mostly in relation to organization commitment and in the public and business sector (Mabaso and Dlamini, 2017). The importance of job satisfaction cannot be over emphases because of its strong relationship with several work attitudes. Therefore, this paper finds it necessary to examine the variable of Job satisfaction of faculty members in private institutions of higher learning in relations to compensation practices in the Eastern Province of Saudi Arabia

\subsection{Compensation}

Compensation is what employees get in return for carrying out assigned work. It is all the short and long term service incentives and benefits as well as salary an employee receives for agreeing to work in an organization (Nawab and Bhatti, 2011). This makes compensation much more than just salary. Compensation includes both indirect and direct financial benefits given to an employee. Financial Compensation is the monetary remunerations given by organizations to employees in exchange for service rendered. According to Gupta (2014), 
employee receives financial compensation at defined period and they can be classified as follows: rent allowance, basic salary, conveyance, leave allowance, medical Insurance, special allowances, gratuity and bonus.

a. Rent Allowance: To motivate employees and make them socially secure, organization provides them with rent allowances. In addition, when employees are from different location/country from place of work, they are provided with accommodation.

b. Basic Salary: This refers to agree upon money received by an employee in exchanged for work carried out for the organization at a particular time.

c. Conveyance: This is the provision of transportation facilities or allowances in order to motivate employees.

d. Leave Allowance: This is the provision for either paid leave or allowances for employees and sometimes family members are included in this compensation practice.

e. Medical claims: Employees health and well-being are catered for by organizations with the provisions of medical insurance or refund of medical bills for themselves and most times certain numbers of immediate family members.

f. Special Allowance: In order to motivate employees for improved output, organization provides this financial compensation that includes allowance for meal, low interest loans, overtime, communication allowances, travel allowances etc.

g. Gratuity: This is the allowance given to employees at the end of successful service with the organization.

h. Bonus: This is allowances that may amount to a month's pay given to an employee at certain time of the year in order to increase motivation.

The amount of all the above financial compensation is given to employees based on their level or position they hold in the organization. It has been stated that to ensure the effectiveness of organization, human resource management practices should give adequate support to compensation practices (Absar et al., 2010; Hafez, AbouelNeel and Elsaid, 2017).

Additionally, it is known that compensation is the total financial rewards organization gives to an employee (Mustafa, 2013). Study has stated that financial compensation plays key part in the determination of employee's job satisfaction (Qasim, Cheema and Syed, 2012). This is because compensation practice is one of the core elements in determining employee's job satisfaction.

Growing social and psychosocial needs of employees has forced them to look for employment with high financial benefits. Furthermore, dissatisfaction would arise if employees feel they are not adequately compensated. This feeling of dissatisfaction could gradually grow if it is not checked. It has been argued that when employees feel that they are not adequately paid their monthly wages, dissatisfaction arises and sometimes leading to turnover (Greenberg and Baron, 2008). Furthermore, study has opined that when the most 
impelling compensation practice is known and implemented, it goes a long way in improving satisfaction and commitment of faculty members (Khan et al., 2014).

Studies have reported significant relationship between compensation practices and job satisfaction (Mangi et al., 2011; Nawab and Bhatti, 2011; Salisu, Chinyio and. Suresh, 2015). In addition, salary has been reported to have significant influence on job satisfaction of lecturers (Mustafa, 2013; Noordin and Jusoff, 2009). Remunerations which is among financial compensation has been argued to have effect on job satisfaction of faculty members in higher institution of learning (Mafini and Dlodlo, 2014; Nawab and Bhatti, 2011).

However, studies have found that compensation in form of remuneration has only moderate relationships with job satisfaction. (Sohail and Delin, Al-Hinai and Bajracharya, 2014) Furthermore, studies also found insignificant relationship between fringe benefits and job satisfaction (Mabaso, \& Dlamini, 2017; Noor, 2013). Therefore, this paper hypothesizes that:

H1: Compensation practices have significant relationship with Job satisfaction of faculty members in newly established private institutions of higher learning Saudi Arabia.

\subsection{Talent Management}

The concept of talent management has been defined differently by studies in the context of various research (Hamidi et al. 2014; Lewis and Heckman, 2006; Vaiman et al., 2012). Talent management has been viewed in the perspective of human capital (Cappelli, 2008), a necessary factor for active organizational strategy (Cheloha and Swain, 2005) and as a process to make sure employees are performing at their utmost abilities (Redford, 2005). Whatever the context of the research, talent management is simply an integrated system that is used to recruit, develop and retain the human capital of any organization (Beechler and Woodward, 2009; Hamidi et al., 2014).

Talent management in the present era is considered competitive, highly demanded, high speed and very necessary in the achievement of organizational set goals (Almaaitah et al., 2020). In the ever increasing, uncertain, dynamic work and business environment, talent management has high importance in achieving competitive advantage that is sustainable (Meyers and Van Woerkom, 2014). Through talent management organization places the right employees in the right job positions in accordance with required skills for the overall organizational goals (Doh et al., 2011; Collings and Mellahi, 2009; Hamidi et al. (2014). Thereby maximizing and utilizing adequately the human capital talent pool.

Talent management has been found to have significant relationship with job satisfaction in an educational setting (Hafez et al., 2017). Furthermore, a positive relationship has been reported in the relationship between talent management and human resource practices (Boxall and Macky, 2014). In the information technology world, a strong correlation was reported between talent management and compensation (Rani and Joshi, 2012). Additionally, talent management was found to mediate the relationship between human resource management practices and organizational success (Karam, Ab-Yazid, Khatibi and Azam, 2017). Therefore, this paper hypothesizes that: 
H2: Compensation practices have significant relationship with Talent Management of faculty members in newly established private institutions of higher learning Saudi Arabia

H3: Talent Management has significant relationship with Job satisfaction of faculty members in newly established private institutions of higher learning Saudi Arabia

H4: Talent Management mediates the relationship between compensation Practices and Job satisfaction of faculty members in newly established private institutions of higher learning Saudi Arabia.

\section{Method}

A descriptive research design method was applied in the study. The paper was developed from reviewed of past literatures on compensation practices on job satisfaction from online data bases and other periodicals as well as manual text and unpublished resources. This was done to highlight the mediating role of talent management in the relationship between compensation practices and job satisfaction of faculty members particularly in newly established private institutions of higher learning in Saudi Arabia. Based on the reviewed literature and the hypotheses developed, the proposed theoretical framework for this paper is shown in Figure 1 below.

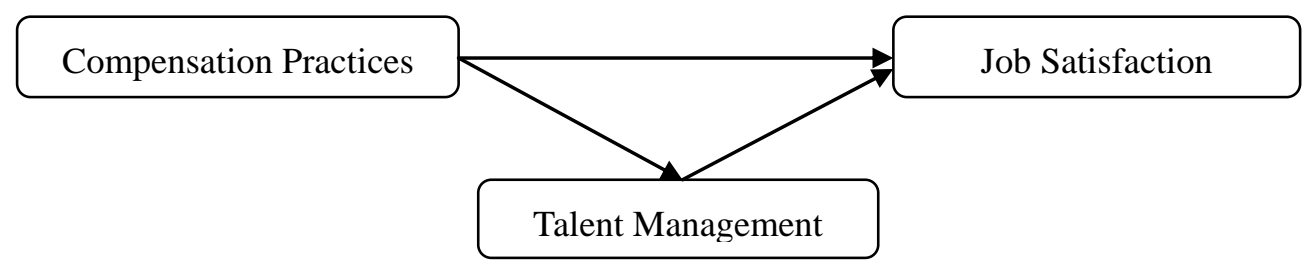

Figure1. Proposed Research Framework

\section{Discussions}

This paper objective is to examine the mediating role of talent management in the relationship between compensation practices and job satisfaction. A descriptive explanation was done through literature review from online databases of the paper variables. This was done to give an in-depth view of the paper concept on talent management, compensation practices and job satisfaction with regards to faculty members in private institution of higher learning in Saudi Arabia.

The increasing demand to employ skilled talents in organizations and the zeal of empowered employees to switch to valuable positions only happens when institutions put in place strategies and adhere to procedures and policies of talent management. A well planned compensation practices that leads to employee retention due to job satisfaction indicates a working system of talent management for the overall achievement of organizational goals (Hamidi et al., 2014).

Therefore, in order to attract as well as keep talented faculty members, there is need to design and implement top notch compensation practices (Mabaso, and Dlamini, 2017) by private institutions of higher learning in Saudi Arabia through having a clear understanding of faculty 
members needs and expectations. This can only be attained if policies makers in these institutions of higher learning understand nature of compensation practices (Al-Hinai and Bajracharya, 2014) ensuring that organization justice and equity plays significant role in compensation distribution (Karim and Rehman, 2012; Singh, et al., 2012).

Remuneration as a form of compensation is an appropriate motivator because employees work in exchange for pay hence worthy remuneration should be given to attract and retain competent human resource talent (Hafez et al., 2017; Ibrahim and Boerhaneoddin, 2010; Mustafa, 2013). This can ensure the feeling of satisfaction and thus commitment to organizational goals. Understanding the intricacies of compensation practices can assist policies makers design the appropriate compensation packages (Mangi et al., 2011) for faculty members of these private institutions of higher learning in Saudi Arabia where the competitive environment is fair, workload is reasonable and policies implementation is fair.

Furthermore, more emphasis should be given to rewarding training and development. Sponsoring employee's training and giving reward for research publications can go a long way in improving faculty member's job satisfaction (Hafez et al., 2017; Mustafa, 2013; Nawab and Bhatti, 2011). This is because these practices indicate that the organization encourages self-development which leads to better job performance and achievement of set organizational goals (Hafez et al., 2017).

In addition, the practice of timely employee's promotion is another compensation practice that leads to job satisfaction (Mabaso, and Dlamini, 2017). This is because it signifies achievement and achievement most times means more remuneration. Timely promotion is compensation practice that indicates equity and organizational justice (Karim and Rehman, 2012). Policies makers should remember that employee's feeling of organizational justice is a strong motivation and determinant of job satisfaction.

Compensation practices with organization equity that leads to job satisfaction (Absar et al., 2010; Mustapha, 2013) indicates that the institution has adequate talent management system (Kamal, and Lukman, 2017; Al-Hinai and Bajracharya, 2014).This shows that the role of talent management in bringing about achievement of organizational goals (Almaaitah et al., 2020) from the job satisfaction (Hafez et al., 2017) of faculty members in private institution of higher learning through equitable compensation practice cannot be over emphasized (Al-Hinai and Bajracharya, 2014).

By explaining the relationships between the paper variables through literature review, this paper has contributed to the exiting literature on talent management, compensation practices and job satisfaction with particular focus on faculty members in private institutions of higher learning in Saudi Arabia. With regards to future research, the paper provides scholars with opportunity to test empirically the proposed framework in similar of other research settings. In addition other variables can be added to the proposed framework.

\section{References}

Absar, M. M. N., Azim, M. T., Balasundaram, N., \& Akhter, S. (2010). Impact of human resources practices on job satisfaction: Evidence from manufacturing firms in Bangladesh. 
Economic and Science Service, 62, 31-42.

Albaqami, A. S. (2016). Determinants of turnover intention among faculty members in Saudi public universities (Doctoral dissertation, University of Salford).

Al Hinai, Z., \& Bajracharya, A. (2014, October). A study on the factors affecting job satisfaction of academic staff in higher education institution. In Proceedings of International Academic Conferences (No. 0800160). International Institute of Social and Economic Sciences.

Almaaitah, M., Alsafadi, Y., Altahat, S., \& Yousfi, A. (2020). The effect of talent management on organizational performance improvement: The mediating role of organizational commitment. Management Science Letters, 10(12), 2937-2944. https://doi.org/10.5267/j.msl.2020.4.012

Beechler, S., \& Woodward, C. (2009). The global "war for talent". Journal of International Management, 15(3), 273-285. https://doi.org/10.1016/j.intman.2009.01.002

Boxall, P., \& Macky, K. (2014). High-involvement work processes, work intensification and employee well-being. Work Employment \& Society, June 1. https://doi.org/10.1177/0950017013512714

Bustamam, F. L., Teng, S. S., \& Abdullah, F. Z. (2014). Reward management and job satisfaction among frontline employees in hotel industry in Malaysia. Proc. Social Behavior. Science., 144, 392-402. https://doi.org/10.1016/j.sbspro.2014.07.308

Cappelli, P. (2008). Talent management for the twenty-first century. Harvard Business Review, 86(3), 74-81.

Cheloha, R., \& Swain, J. (2005). Talent management system key to effective succession planning. Canadian HR Reporter, 18(17), 5-8.

Collings, D., \& Mellahi, K., (2009), Strategic Talent Management; a review and research agenda. Human Resource Management Review, 19(4), 304-313. https://doi.org/10.1016/j.hrmr.2009.04.001

Doh, P., Stumpf, S., \& Tymon, W. (2011). Supplement 1: Responsible Leadership. Journal of Business Ethics, 98, 85-100. https://doi.org/10.1007/s10551-011-1018-3

Greenberg, J., \& Baron, R. A. (2008). Behaviour in Organizations. 9th Edn., Pearson Education Inc., Upper Saddle River, New Jersey.

Gupta, M. (2014). Employees' satisfaction towards monetary compensation practices. Global Journal of Finance and Management, 6(8), 757-764.

Hamidi, N., Saberi, H., \& Safari, M. (2014). The effect of implementation of talent management on job satisfaction governmental organizations (Case Study: Ministry of Roads and Urban). Journal of Novel Applied Sciences, 3(1), 100-113.

Hafez, E., AbouelNeel, R., \& Elsaid, E. (2017). An exploratory study on how talent 
management affects employee retention and job satisfaction for personnel administration in Ain Shams University Egypt. Journal of Management and Strategy, 8(4), 1. https://doi.org/10.5430/jms.v8n4p1

Ibrahim, I. I., \& Boerhaneoddin, A. (2010). Is job satisfaction mediating the relationship between compensation structure and organizational commitment? A study in the Malaysian power utility. J. Global Bus. Econ., 1(1), 43-61

Ismail, A., \& Abd Razak, M. R. (2016). A study on job satisfaction as a determinant of job motivation. Acta Universitatis Danubius. Economica, 12(3).

Kamal, M. Y., \& Lukman, Z. M. (2017). The influence of talent management practices on job satisfaction. International Journal of Academic Research in Business and Social Sciences, 7(7), 859-864. https://doi.org/10.6007/IJARBSS/v7-i7/3159

Karam, A. K. D., Ab Yazid, M. S., Khatibi, A., \& Azam, S. F. (2017). Measuring the Mediating Role of Talent Management, HRM and Organisational Success in UAE. European Journal of Human Resource Management Studies.

Karim, F., \& Rehman, O. (2012). Impact of job satisfaction, perceived organizational justice and employee empowerment on organizational commitment in semi-government organizations of Pakistan. Journal of Business Studies Quarterly, 3(4), 92.

Khan, M. S., Khan, I., Kundi, G. M., Khan, S., Nawaz, A., Khan, F., \&. Yar, N. B. (2014). The impact of job satisfaction and organizational commitment on the intention to leave among the academicians. Int. J. Acad. Res. Bus. Social Sci., 4, 114-131. https://doi.org/10.6007/IJARBSS/v4-i2/610

Lewis, R. E., \& Heckman, R. J. (2006). Talent management: A critical review. Human Resource Management Review, 16(2), 139- 154. https://doi.org/10.1016/j.hrmr.2006.03.001

Mabaso, C. M., \& Dlamini, B. I. (2017). Impact of compensation and benefits on job satisfaction. Research Journal of Business Management, 11(2), 80-90. https://doi.org/10.3923/rjbm.2017.80.90

Mangi, R. A., Soomro, H. J., Ghumro, I. A., Abidi, A. R., \&. Jalbani, A. A. (2011). A study of job satisfaction among non- PHD faculty in universities. Australian. Journal of Business and Management Review, 1, 83-90.

Meyers, M. C., \& Van Woerkom, M. (2014). The influence of underlying philosophies on talent management: Theory, implications for practice, and research agenda. Journal of World Business, 49(2), 192-203. https://doi.org/10.1016/j.jwb.2013.11.003

Mustapha, N. (2013). The influence of financial reward on job satisfaction among academic staffs at public universities in Kelantan, Malaysia. International. Journal of. Business and social science, 4, 244-248.

Moloantoa, M. E. (2015). Factors affecting job satisfaction of academic employees: A case study of the National University of Lesotho. Master's Thesis, Durban University of 


\section{Macrothink}

Technology, Durban.

Nawab, S., \& Bhatti, K. K. (2011). Influence of employee compensation on organizational commitment and job satisfaction: A case study of educational sector of Pakistan. International Journal of Business and Social Science, 2(8).

Noor, K. M. (2013). Job satisfaction of academics in Malaysian public higher education institutions. Masters Thesis, La Trobe University, Melbourne.

Noordin, F., \& Jusoff, K. (2009). Levels of job satisfaction amongst Malaysian academic staff. Asian social science, 5(5), 122-128. https://doi.org/10.5539/ass.v5n5p122

Ombima, H. P. A. (2014). Factors affecting employee job satisfaction in institutions of higher education in Kenya: A case study of United States international University (USIU) (Doctoral dissertation, United States International University-Africa).

Qasim, S. F., Cheema, E. A., \& Syed, N. A. (2012). Exploring factors affecting employee's job satisfaction at work. Journal of Management and Social Science, 8, 31-39

Rani, A., \& Joshi, U. (2012). A study of talent management as a strategic tool for the organization in selected Indian IT Companies. European Journal of Business and Management, 4(4), 20-28.

Redford, K. (2005, September). Shedding light on talent tactics. Personnel Today, 20-22.

Salisu, J. B., Chinyio, E., \& Suresh, S. (2015). The impact of compensation on the job satisfaction of public sector construction workers of Jigawa state of Nigeria, Business Management. Review, 6, 282-296.

Singh, A., Jones, D. B., \& Hall, N. (2012). Talent management: A research based case study in the GCC region. International Journal of Business and Management, 7(24), 94. https://doi.org/10.5539/ijbm.v7n24p94

Sohail, M. T., \& Delin, H. (2013). Job satisfaction surrounded by academic society. American Sociologist, 16, 177-180.

Vaiman, V., Scullion, H., \& Collings, D. (2012). Talent management decision making. Management Decision, 50, 925-941. https://doi.org/10.1108/00251741211227663

\section{Copyright Disclaimer}

Copyright for this article is retained by the author(s), with first publication rights granted to the journal.

This is an open-access article distributed under the terms and conditions of the Creative Commons Attribution license (http://creativecommons.org/licenses/by/4.0/). 